\title{
A CRITICAL ANALYSIS OF AN INTERPROFESSIONALISM ASSESSMENT SCALE APPLIED TO HEALTH SCIENCES UNDERGRADUATE STUDENTS
}

Carolina Pedroza de Carvalho Garcia', Marta Silva Menezes ${ }^{2}$, Carolina Villa Nova Aguiar ${ }^{3}$, Marilia Menezes Gusmão ${ }^{4}$, Ligia Vilas Boas ${ }^{5}$, Liliane Lins ${ }^{6}$

Corresponding author: Marta Silva Menezes - martamenezes@bahiana.edu.br 'MSc in Nursing. Extension Activities Assistant Dean at BAHIANA - School of Medicine and Public Health. Professor at the State University of Bahia and at BAHIANA - School of Medicine and Public Health. Salvador, Bahia, Brazil. ${ }^{2} \mathrm{PhD}$ in Medicine and Health. Professor at BAHIANA - School of Medicine and Public Health. Salvador, Bahia, Brazil. ${ }^{3} \mathrm{PhD}$ in Psychology. Professor at BAHIANA - School of Medicine and Public Health. Salvador, Bahia, Brazil. ${ }^{4} \mathrm{MD}$. Salvador, Bahia, Brazil.

${ }^{5} \mathrm{MSc}$ in Health Technologies. Pedagogical advisor at BAHIANA - School of Medicine and Publich Health. Salvador, Bahia, Brazil. ${ }^{6}$ Postdoctor in Medicine and Human Health. Stomatologist at the University Hospital Professor Edgar Santos and at the Oral Care Program for Pregnant Women, Elderly and Special Patients at the Federal University of Bahia. Professor at the Federal University of Bahia and at BAHIANA School of Medicine and Human Health. Salvador, Bahia, Brazil.

\begin{abstract}
Introduction: The search for initiatives that stimulate interprofessionalism should incorporate activities developed by educational institutions. The BAHIANA - School of Medicine and Public Health (EBMSP) runs a project, approved by the Government Program of Education for Work in Health - PET-Saúde, which promotes interprofessional practice. Objective: Evaluate the psychometric properties of the IEPS when applied to Brazilian students. Method: We conducted an Exploratory Factorial Analyses and took into account the eigenvalues and the theoretical model in order to estimate the number of factors. The Cronbach alpha coefficient was also calculated. Results: A three-dimensional factorial solution was tested. These three factors jointly explain $66.5 \%$ of variance in interprofessionalism. Three items were excluded, due to empirical weaknesses. The Cronbach alphas obtained for each dimension were $0.84,0.70$ and 0.16 . Conclusion: The study attained its objective, gathering initial evidence regarding the validity of this measure in a Brazilian context.
\end{abstract}

Keywords: Interprofessional Relations; Education; Students, Health Occupations; Interdisciplinary Research 
Technological and scientific advances have led to greater specialization in theoretical and practical knowledge in health sciences and, as a consequence, to the fragmentation of its disciplines. Rather than contributing to a better understanding of phenomena, however, due to its complexity, an excess of fragmentation has begun to hamper comprehension. This has created the need for a reorganization of knowledge, through a search for common denominators between the several fields of knowledge: interdisciplinarity arises from just this scenario ${ }^{1,2}$.

Since the relevance of interdisciplinarity has been recognized, it has become essential to reform processes for the construction and socialization of knowledge. Such practices are essentially aimed at maximizing the benefits provided to patients through cooperation between different professionals ${ }^{3}$.

The search for initiatives that stimulate interprofessionalism should incorporate activities developed by educational institutions. By promoting the integration of health courses into the teaching and service process, the Government Program of Education for Work in Health - PET-Saúde, promotes interprofessionalism. The BAHIANA - School of Medicine and Public Health (EBMSP) runs a project approved by this government program ${ }^{4}$.

The Interdisciplinary Education Perception Scale (IEPS) was developed to evaluate attitudinal changes to interdisciplinary work ${ }^{3}$. The IEPS version proposed and validated by the authors consisted of an attitudinal inventory composed of 18 items, distributed across four distinct dimensions: 1 . Competence and autonomy ( 8 items, $\alpha=0.82$ ); 2. Perceived need for cooperation ( 2 items, $\alpha=$ 0.56 ); 3. Perception of actual cooperation (5 items, $\alpha=0.54) ; 4$. Understanding the value of other professionals ( 3 items, $\alpha=0.52$ ).

The IEPS has been widely adopted in research on interdisciplinarity ${ }^{5,6,7}$. In 2007, a study was published analyzing its psychometric properties when applied to a new participant sample ${ }^{8}$. In this study, the authors proposed a reformulation of the instrument, which involved withdrawing one of its dimensions - understanding the value of other professionals - and excluded certain items from the other dimensions. The reformulated version of the IEPS was composed of 12 items distributed across three dimensions: 1. Competence and autonomy (5 items, $\alpha=0,79$ ); 2. Perceived need for cooperation ( 2 items, $\alpha=$ $0.40) ; 3$. Perception of actual cooperation (5 items, $\alpha=0.83)$. Subsequently, Leitch $(2013)^{9}$ conducted a comparative study between the structures proposed by Luecht et al. (1990) $)^{3}$ and McFadyen et al. $(2007)^{8}$, asserting that the solution suggested by the latter authors it a better fit for application to undergraduate students.

In Brazil, the IEPS scale was translated by a group of researchers for exclusively didactic purposes. The translated version has been used in training workshops for health professionals. However, no studies have been conducted regarding the psychometric adequacy of the scale in its Portuguese translation.

This article aims to evaluate the psychometric properties of the IEPS when applied to Brazilian students. We applied the 12-item version, since it represents an improvement over the original scale.

\section{METHOD}

\section{Participants}

The sample consisted of 84 students, all candidates for admission to the PET-Health / Networks program at EBMSP. Of the 84 participants, $76.2 \%$ were female, $58.3 \%$ were in their fifth semester at the time of the research, while the remaining $41.7 \%$ were in their sixth. The courses included in the study were medicine $(54.8 \%)$, nursing $(31 \%)$ and psychology (14.2\%).

The study was approved by the local ethics committee (CAAE 57164216.1.0000.5544). Informed consent was obtained from all participants. 


\section{Instrument:}

The Interdisciplinary Education Perception Scale (IEPS) was used in its Portuguese translation. In response to the scale, the participant was invited to express their degree of agreement with each of the items on a 6-point Likert scale $(1=$ totally disagree to $6=$ strongly agree). The original items in the English language $(3,8)$ and their respective translations may be found in Table 1 .

\section{Data analysis:}

Initially, the Kaiser-Meyer-Olkin Measurement of
Sampling Adequacy (KMO) and Bartlett's sphericity test were analyzed for factor matrix checkability. The factorial structure of the scale was then evaluated through Exploratory Factorial Analysis (EFA), using the Principal Axis Factoring (PAF) extraction method and Direct Oblimin rotation. In order to estimate the number of factors, the eigenvalues were observed and, to complement this, the theoretical model adopted to construct the scale was considered as a criterion for factor definition. In order to verify internal reliability, the Cronbach alpha coefficient was calculated for each dimension, with values at or above 0.70 considered acceptable, and indices starting at 0.80 as highly reliable ${ }^{10}$.

Table 1. Original and Portuguese translated versions of the items in the Interdisciplinary Education Perception Scale (IEPS)

\begin{tabular}{|c|c|}
\hline English version & Portuguese translated version \\
\hline $\begin{array}{l}\text { 1. Individuals in my profession } \\
\text { are well-trained }\end{array}$ & $\begin{array}{l}\text { 1. Indivíduos na minha profissão são bem } \\
\text { treinados }\end{array}$ \\
\hline $\begin{array}{l}\text { 2. Individuals in my profession are able to } \\
\text { work closely }\end{array}$ & $\begin{array}{l}\text { 2. Indivíduos na minha profissão são } \\
\text { capazes de trabalhar próximo com } \\
\text { indivíduos de outras profissốes c }\end{array}$ \\
\hline $\begin{array}{l}\text { 3. Individuals in my profession are very } \\
\text { positive about their goals and objectives }\end{array}$ & $\begin{array}{l}\text { 3. Indivíduos na minha profissão são muito } \\
\text { positivos acerca de seus objetivos a }\end{array}$ \\
\hline $\begin{array}{l}\text { 4. Individuals in my profession need to } \\
\text { cooperate with other professions }\end{array}$ & $\begin{array}{l}\text { 4. Indivíduos na minha profissão precisam } \\
\text { cooperar com outras profissões b }\end{array}$ \\
\hline $\begin{array}{l}\text { 5. Individuals in my profession are very } \\
\text { positive about their contributions and } \\
\text { accomplishments }\end{array}$ & $\begin{array}{l}\text { 5. Indivíduos na minha profissão são muito } \\
\text { positivos acerca de suas contribuiçốes e } \\
\text { realizaçốes a }\end{array}$ \\
\hline $\begin{array}{l}\text { 6. Individuals in my profession must } \\
\text { depend upon the work of people in other } \\
\text { professions }\end{array}$ & $\begin{array}{l}\text { 6. Indivíduos na minha profissão devem } \\
\text { depender do trabalho de outras } \\
\text { profissóes b }\end{array}$ \\
\hline $\begin{array}{l}\text { 7. Individuals in my profession trust each } \\
\text { other's professional judgment }\end{array}$ & $\begin{array}{l}\text { 7. Indivíduos na minha profissấo } \\
\text { acreditam no julgamento das outras } \\
\text { profissóes a }\end{array}$ \\
\hline $\begin{array}{l}\text { 8. Individuals in my profession are } \\
\text { extremely competent }\end{array}$ & $\begin{array}{l}\text { 8. Indivíduos na minha profissão são } \\
\text { extremamente competentes a }\end{array}$ \\
\hline $\begin{array}{l}\text { 9. Individuals in my profession are willing } \\
\text { to share information and resources with } \\
\text { other professionals }\end{array}$ & $\begin{array}{l}\text { 9. Indivíduos na minha profissão desejam } \\
\text { dividir informações com e recursos com } \\
\text { outras profissões c }\end{array}$ \\
\hline $\begin{array}{l}\text { 10. Individuals in my profession have } \\
\text { good relations with people in other } \\
\text { professions }\end{array}$ & $\begin{array}{l}\text { 10. Indivíduos na minha profissão têm } \\
\text { boa relaçấo com pessoas de outra } \\
\text { profissãoc }\end{array}$ \\
\hline $\begin{array}{l}\text { 11. Individuals in my profession think } \\
\text { highly of other related professions }\end{array}$ & $\begin{array}{l}\text { 11. Indivíduos na minha profissão pensam } \\
\text { fortemente na minha profissão c }\end{array}$ \\
\hline $\begin{array}{l}\text { 12. Individuals in my profession work well } \\
\text { with each other }\end{array}$ & $\begin{array}{l}\text { 12. Indivíduos na minha profissấo } \\
\text { trabalham bem com os demais c }\end{array}$ \\
\hline
\end{tabular}

$a=$ competence and autonomy; $b=$ Perception of need for collaboration; $c=$ Perception of real cooperation 


\section{RESULTS}

In the EFA, the KMO was 0.718 and Bartlett's sphericity test was significant ( $p<.001$ ), ensuring matrix factorability. In order to estimate the factors, we initially considered the eigenvalue criterion, which suggested the existence of up to four factors, as seen in Table 2.

Table 2. Number of factors suggested in the IEPS by Eigenvalue criterion ( 12 items)

\begin{tabular}{c|c|c|c}
\hline Factors & Eigenvalues & $\begin{array}{c}\% \\
\text { Variance }\end{array}$ & $\begin{array}{c}\% \\
\text { Accumulated } \\
\text { variance }\end{array}$ \\
\hline 1 & 3.892 & 32.436 & 32.436 \\
\hline 2 & 1.837 & 15.309 & 47.745 \\
\hline 3 & 1.248 & 10.400 & 58.145 \\
\hline 4 & 1.137 & 9.472 & 67.617 \\
\hline 5 & .925 & 7.709 & 75.326 \\
\hline 6 & .726 & 6.048 & 81.374 \\
\hline 7 & .658 & 5.484 & 86.858 \\
\hline 8 & .492 & 4.102 & 90.959 \\
\hline 9 & .400 & 3.334 & 94.293 \\
\hline 10 & .297 & 2.472 & 96.765 \\
\hline 11 & .265 & 2.207 & 98.972 \\
\hline 12 & .123 & 1.028 & 100.000 \\
\hline
\end{tabular}

From the combination of the eigenvalue criterion and the theoretical model, a three-dimensional factorial solution was tested, in line with predictions in the international literature ${ }^{8,9}$. Table 3 presents the item distribution by factor and respective factorial loads.

Table 3. Factorial loads of the IEPS Tri-factor Solution composed of 12 items

\begin{tabular}{|c|c|c|c|}
\hline \multirow[b]{2}{*}{ Items } & \multicolumn{3}{|c|}{ Factors } \\
\hline & 1 & 2 & 3 \\
\hline 12. Individuals in my profession work well with each other. & .890 & & \\
\hline $\begin{array}{l}\text { 10. Individuals in my profession have good relations with people in other } \\
\text { professions. c }\end{array}$ & .858 & & \\
\hline $\begin{array}{l}\text { 9. Individuals in my profession are willing to share information and resources } \\
\text { with other professionals c }\end{array}$ & .734 & & \\
\hline 2. Individuals in my profession are able to work closely c & .564 & & \\
\hline 8. Individuals in my profession are extremely competent a & .558 & $\begin{array}{c}- \\
.313\end{array}$ & \\
\hline 7. Individuals in my profession trust each other's professional judgment ${ }^{\circ}$ & & & \\
\hline 11. Individuals in my profession think highly of other related professions c & .301 & .722 & \\
\hline 4. Individuals in my profession need to cooperate with other professions b & & .400 & \\
\hline $\begin{array}{l}\text { 6. Individuals in my profession must depend upon the work of people in other } \\
\text { professions }{ }^{b}\end{array}$ & & .384 & \\
\hline $\begin{array}{l}\text { 3. Individuals in my profession are very positive about their goals and } \\
\text { objectives }\end{array}$ & & .339 & .315 \\
\hline $\begin{array}{l}\text { 5. Individuals in my profession are very positive about their contributions and } \\
\text { accomplishments a }\end{array}$ & & & .826 \\
\hline 1. Individuals in my profession are well-trained a & & & .554 \\
\hline
\end{tabular}

Looking at the EFA results (Table 3), we can observe that four items presented empirical behavior divergent from expectations, according to the theoretical model we adopted: item 7 did not present a factorial load for any of the factors, items 8 and 11 presented high factor loads for factors not congruent with expected semantic representations, and finally, item 3 presented factorial ambiguity.

In view of these results, we decided to withdraw items 7,8 and 11 and conduct a new EFA on the remaining 
items. The decision to maintain item 3 for the next phase was because it had a factorial load within the correct dimension, and its factorial ambiguity may have been derived from empirical confusion caused by items 8 and 11 (which obtained factor loads not congruent with theory).

In the new EFA, the obtained KMO was 0.712 and Bartlett's sphericity test was significant $(p<.001$ ), attesting, once again, to data matrix adequacy. According to Table 4, the eigenvalue criterion predicts the existence of up to three different factors.

Table 4. Number of factors suggested in the IEPS by Eigenvalue criterion ( 9 items)

\begin{tabular}{c|c|c|c}
\hline Factors & Eigenvalues & $\begin{array}{c}\% \\
\text { Variance }\end{array}$ & $\begin{array}{c}\% \text { Accumulated } \\
\text { variance }\end{array}$ \\
\hline 1 & 3.304 & 36.708 & 36.708 \\
\hline 2 & 1.640 & 18.223 & 54.931 \\
\hline 3 & 1.044 & 11.604 & 66.535 \\
\hline 4 & .807 & 8.971 & 75.506 \\
\hline 5 & .786 & 8.729 & 84.235 \\
\hline 6 & .543 & 6.038 & 90.273 \\
\hline 7 & .406 & 4.508 & 94.782 \\
\hline 8 & .334 & 3.712 & 98.494 \\
\hline 9 & .136 & 1.506 & 100.000 \\
\hline
\end{tabular}

In Table 4, we can see that these three factors jointly explain $66.5 \%$ of the explained variance of the phenomenon in question - interprofessionalism. From the factorial loads obtained by these items (Table 5), we can observe that the first factor grouped four items related to the perception of actual cooperation; the second involved three items regarding competence and autonomy, while, for its part, the third factor grouped the two items regarding the perceived need for cooperation. The Cronbach alphas obtained for each of the dimensions were $0.84,0.70$ and 0.16 , respectively.

Table 5. Factorial loads of the IEPS Tri-factor Solution composed of nine items

\begin{tabular}{|c|c|c|c|}
\hline \multirow[b]{2}{*}{ Items } & \multicolumn{3}{|c|}{ Factors } \\
\hline & 1 & 2 & 3 \\
\hline $\begin{array}{l}\text { 12. Individuals in my profession work well with each other. } \\
\text { 10. Individuals in my profession have good relations with people in } \\
\text { other professions. } \\
\text { 2. Individuals in my profession are able to work closely. } \\
\text { 9. Individuals in my profession are willing to share information and } \\
\text { resources with other professionals } \\
\text { 5. Individuals in my profession are very positive about their } \\
\text { contributions and accomplishments } \\
\text { 1. Individuals in my profession are well-trained } \\
\text { 3. Individuals in my profession are very positive about their goals } \\
\text { and objectives } \\
\text { 6. Individuals in my profession must depend upon the work of people } \\
\text { in other professions } \\
\text { 4. Individuals in my profession need to cooperate with other } \\
\text { professions }\end{array}$ & $\begin{array}{l}.929 \\
.849 \\
.587 \\
.552\end{array}$ & $\begin{array}{l}.932 \\
.538 \\
.391\end{array}$ & $\begin{array}{l}.628 \\
.368 \\
11.6\end{array}$ \\
\hline
\end{tabular}




\section{DISCUSSION}

When examining the EFA results, we can confirm that the best solution for the Portuguese version of the IEPS is a scale composed of nine items, distributed across three factors: the first factor - "Perception of actual cooperation" - was the most representative of the phenomenon of interprofessionalism, accounting for $36.7 \%$ of variance. The second factor, called "Competence and autonomy", was able to explain $18.2 \%$ of variance, while the third and last factor, "Perceived need for cooperation", demonstrated the least explanatory power and was responsible for $11.6 \%$ of phenomenon variance.

In order for the factorial solution to be interpretable and compatible with those suggested by international validation studies $3,8,9$, it was necessary to exclude three items. Instrument translation should be considered as a potential reason for the empirical inadequacy of these items. Item 11 is a clear example of this weakness, since the original and translated versions differ significantly in content (Individuals in my profession think highly of other related professions/Indivíduos na minha profissão pensam fortemente na minha profissão) - the focus in the original version is on other professions, while the translated version directs participant's attention to their own profession.

Item 7, for its part, provided a rigorous translation of the original item ("Individuals in my profession believe in the judgment of other professions"). However, it seems pertinent to adapt this to express a more suitable meaning for the Brazilian context, since the term "judgment" has a different connotation from the original item (which, in Portuguese, may represent a personal and evaluative view).

In addition to translation inconsistencies, we note other weaknesses in the translated version of the IEPS, which consist of aspects "inherited" from the original version. For example, in the first version, proposed by Luecht et al. $(1990)^{3}$, the Perceived Need for Cooperation dimension is composed of only two items, which almost inevitably leads to low factor reliability. The results obtained in our study $(\alpha=0.16)$ were lower than those obtained in the studies of Luecht et al. $(1990)^{3}$ and McFadyen et al. (2007)8, however, these surveys had already obtained unsatisfactory reliability values $(\alpha=0.56$ and 0.38 , respectively).

\section{CONCLUSIONS}

This study aimed to evaluate the psychometric properties of the Portuguese version of the IEPS when applied to a sample of Brazilian students. We recognize, however, that the study contained important limitations. Among these are weaknesses regarding the quality of item translation and the low number of participants.

Despite these limitations, the work attained its objective, which was to gather initial evidence of the validity of the measure in the Brazilian context. We recommend further studies for this research agenda, which should include a careful review of the measure (preferably proposing improvements in terms of the quantity and quality of items), followed by a new application, with a larger sample, with greater variability and a re-evaluation of the psychometric properties obtained.

\section{COMPETING INTERESTS}

No financial, legal or political competing interests with third parties (government, commercial, private foundation, etc.) were disclosed for any aspect of the submitted work (including but not limited to grants, data monitoring board, study design, manuscript preparation, statistical analysis, etc.).

\section{REFERENCES}

1. Coimbra, JAA. Considerações sobre a interdisciplinaridade. In: Philippi Jr, A. (Org.) Interdisciplinaridade em Ciências Ambientais. São Paulo: Signus; 2000. Portuguese.

2. Thiesen, JS. A interdisciplinaridade como um movimento articulador no processo ensino-aprendizagem. Revista Brasileira de Educação. 2008; 13(39):545-598. doi: 10.1590/S1413-24782008000300010. Portuguese. 
3. Luecht, RM, Madsen, MK, Taugher, MP, Petterson, BJ. Assessing Professional Perceptions: Design and Validation of an Interdisciplinary Education Perception Scale. Journal of Allied Health. 1990;19(2):181-191.

4. Brasil. Ministério da Saúde. Edital no 14, de 8 de março de 2013 seleção para o programa de educação pelo trabalho para a saúde/rede de atenção à saúde - pet/ saúde redes de atenção à saúde - 2013/2015. Diário Oficial da União. $N^{\circ}$ 47, p. 116, seção 3. Brasília. DF. 2013. Portuguese.

5. Goelen, G, Clercq, G, Huyghens, L, Kerckhofs, E. Measuring the effect of interprofessional problem-based learning on the attitudes of undergraduate health care students. Medical Education. 2006;40(6):555-561. doi: $10.1111 / \mathrm{i} .1365-2929.2006 .02478 . x$

6. Hawk, C, Buckwalter, K, Byrd, L, Cigelman, S. Health professions students' perception of interprofissional relationships. Academic Medicine. 2002;77(4):354-357.

7. Neill, M, Hayward, KS, Perterson, T. Students' perceptions of the interprofessional team in practice through the application of servant leadership principles. Journal of Interprofessional Care. 2007;21 (4):425-432. doi: $10.1080 / 13561820701443512$

8. McFadyen, AK, Maclaren, WM, Webster, VS. The Interdisciplinary Education Perception Scale (IEPS): An alternative remodelled sub-scale structure and its reliability. Journal of Interprofessional Care. 2007;21 (4):433-443. doi: $10.1080 / 13561820701352531$

9. Leicht, J. Exploring psychometric properties of the interdisciplinary education perception scale in health graduate students. Journal of Interprofessional Care. 2013;28(1):52-57. doi: 10.3109/13561820.2013.820691

10. Hair Jr., JF, Anderson, RE, Tatham, RL, Black, WC. Análise multivariada de dados. Bookman: Porto Alegre; 2005.

Portuguese. 